\title{
Activity of the Enzyme Gamma-Glutamyl Transferase (GGT) as a Prognostic Tool for Heart Failures
}

\author{
Susan J. Ali1 ${ }^{*}$, Ayoub A. Bazzaz ${ }^{2}$, Abdulwadood I. Arif ${ }^{1}$ \\ ${ }^{1}$ Department of Chemistry, Faculty of Education, University of Tikrit, Tikrit, Iraq \\ ${ }^{2}$ Department of Basic Sciences, Faculty of Dentistry, University of Kerkuk, Kerkuk, Iraq \\ Email: *susan_jameel@yahoo.com
}

How to cite this paper: Ali, S.J., Bazzaz, A.A. and Arif, A.I. (2017) Activity of the Enzyme Gamma-Glutamyl Transferase (GGT) as a Prognostic Tool for Heart Failures. Advances in Bioscience and Biotechnology, $\mathbf{8}$, 324-341.

https://doi.org/10.4236/abb.2017.89024

Received: July 24, 2017

Accepted: September 27, 2017

Published: September 30, 2017

Copyright ( 2017 by authors and Scientific Research Publishing Inc. This work is licensed under the Creative Commons Attribution International License (CC BY 4.0).

http://creativecommons.org/licenses/by/4.0/

\begin{abstract}
Heart failure (HF) incidence could cause further complications to other body organs, which might sometimes be fatal, and is accompanied by various biochemical alterations i.e. enzymatic changes. The objective of this study was to measure the activity of gamma glutamyl transferase (GGT) as an early diagnostic indicator for HF patients; and to isolate the iso-enzymes for the purpose of finding the Michaelis-Menten constant $(\mathrm{Km})$ and the maximum velocity Vmax of each iso-enzymes which enable follow up the development of HF disease. Samples of blood sera were collected from 120 patients of both genders (70 males and 50 female, aged 30 - 38 years old). Partial purification of iso-enzyme GGT was performed by precipitation, gel filtration, and ion exchange of the two iso-enzyme (I and II). The purity of the enzyme was confirmed by using Sodium dodecyl sulfate-polyacryl amide gel electrophoresis (SDS-PAGE) into two clear bands. The results were compared with other 80 samples of healthy volunteers whose ages ranged between $25-78$ years old, used as control. There has been a significant increase $(p \leq 0.01)$ in the activity of the enzyme GGT in the heart failure patient $(66.9 \pm 1.7 \mathrm{IU} / \mathrm{L})$ in comparison with control $(12.07 \pm 0.60 \mathrm{IU} / \mathrm{L})$. It is concluded that measurements of the iso-enzyme GGT could well benefit as a clear indicator criteria in prognosis of heart failure.
\end{abstract}

\section{Keywords}

Purification, GGT-Enzyme, Heart Failure, Gel-Electrophoresis, Iso-Enzymes-I

\section{Introduction}

To maintain regular homeostasis in the body, various enzymes act as catalysts in 
specific biochemical reaction manners normal and healthy status. Accordingly, any changes in the enzyme levels of the body could indicate a certain body malfunction, disorders detectable by certain biochemical tests. The gamma-glutamyltransferatse (GGT) is an enzyme, of molecular weight 68,000 Dalton found in many tissues, e.g. liver, gallbladder, spleen, pancreas, and kidneys that play a fundamental role in metabolism of glutathione as an anti oxidant agent [1] [2] [3]. The GGT plays a significant role in helping the liver metabolize drugs and other toxins and functions in the body as a transport molecule, helping to move other molecules around the body i.e. glutathione to an acceptor that may be an amino acid, a peptide or water [1] and in degradation of glutathione, drug and xenobiotic detoxification [4]. Other lines of evidence indicate that GGT can also exert a pro-oxidant role, with regulatory effects at various levels in cellular signal transduction and cellular pathophysiology [5].

There is a strong evidence to correlate the raise in GGT level in the sera with the increase in hypertension [6], diabetes, cardiac [7] and other vascular diseases [8]. The activity of the enzyme GGT though could be affected by at least two factors i.e. temperature and $\mathrm{pH}$. The ideal activity of the GGT varies between female (24 IU/L) and male ( $2-30 \mathrm{IU} / \mathrm{L})$ at $37^{\circ} \mathrm{C}$ and $\mathrm{pH} 8.2$ [9]. The GGT test is currently being the most sensitive enzymatic indicator of liver damage which is done in parallel with other tests that measure liver enzymes. Elevated levels of GGT are noted not only in the sera of patients with alcoholic cirrhosis [10] and in primary or secondary (metastatic) neoplasms [11]. Elevated serum values are also seen in patients receiving drugs such as phenytoin and phenobarbital, which are thought to reflect induction of new enzyme activity [12]. Normal values are observed in renal failure and in various muscle diseases e.g. skeletal disease, children older than 1 year and in healthy pregnant women-conditions [13].

The test can also monitor GGT levels for people who have been treated for alcoholic hepatitis as well as in screening for chronic alcohol abuse and to monitor alcohol treatment receivers treatment (alcoholism) or alcoholic hepatitis [14]. Similarly, heart failure (HF), a potentially fatal condition is very common disease worldwide and could suddenly attack various people e.g. in developed countries a percentage of HF reaches $2 \%$ in adults and could increase up to $6 \%-10 \%$ [15]. In the United Kingdom, the disease is the reason for $5 \%$ of emergency hospital admissions [16]. No records are available in Iraq about HF due to lack of central record by Ministry of Health. In such medical conditions, a few enzymatic changes are noticed in many other disorders detectable from blood tests, electrocardiography, and chest radiography to determine the underlying cause of Chronic Heart Failure [17]. Enzymatic changes in the body are carried out via various mechanism and their biological action to body organs vary too pending on a few factors. It is therefore suggested that measurements of GGT enzymatic activity may also be indicative to early risk of heart failure (HF). The activity of GGT therefore is likely to change pending on changes in health condition. The general practitioners (GP) may order the GGT test when in suspect of liver 
damage or at any other liver disorders as it has significance in medicine as a diagnostic marker.

The objective of this research has been to: 1) assess the activity of GGT enzyme levels in sera of the suspected HF patients as an early indicator of the heart failure; and to 2) isolate the iso-enzymes-I for the purpose of finding the MichaelisMenten constant $(\mathrm{Km})$ and the maximum velocity (Vmax) of each iso-enzyme to enable follow up the development of HF disease.

\section{Materials and Methods}

Two hundred blood samples were collected from both genders for the period (November 2012-May 2013) included healthy (control) and patients. Only 120 blood samples of HF patients were obtained from the Tikrit-Teaching Hospital represented 70 male and 50 females sample, between ages of $30-88$ years who have been diagnosed with heart disease based on symptoms and clinical tests such as Electromyo Cardio Gram (ECG) by hospital specialists, laboratory analyst as well as collected information from patients. The control group represented 80 healthy blood sample donors from both males and females (45 males and 35 females) from the blood bank unit at Tikrit Education Hospital aged 25 - 78 years.

\subsection{Estimation of GGT Activity in Serum}

The basic principle of this method is known as Szasz [18]. The equation of interaction can be illustrated as follows:

L- - -Glutamyl-p-nitroanilide + Glycylglycine

L- - -Glutamyl-glycylycine + p-nitroaniline

The rate of the composition of nitroenylin, which is directly proportional to GGT activity in the sample, is measured at $(450 \mathrm{~nm})$. To measure the activity of the GGT enzyme a $1 \mathrm{ML}$ Reagent is incubates at $37^{\circ} \mathrm{C}$ for 30 seconds and then added to 50 ML Specimen or Calibrator. The mixture was well mixed and the absorbance at $(405 \mathrm{~nm})$ was recorded after 30 seconds per minute in 3 minutes.

\subsection{Estimation of the Total Protein Level in Serum}

This principle is based on the activation of the protein-containing serum sample with the basal potassium nitrate solution $\left(\mathrm{Cu}^{2+}\right.$ in a basal environment) known as the Biuret Reagent to give a complex of purple color, the absorption intensity based on the number of peptide bonds in the protein, measured by the absorption intensity at wavelength $(550 \mathrm{~nm})$ [19].

$$
\text { Protein }+\mathrm{Cu}^{2+}+\mathrm{OH}^{-} \longrightarrow \text { violet complex. }
$$

The working method for total protein determination was determined by using $20 \mu \mathrm{L}$ as standard volume against the same amount of serum samples. For reagent 1 (R1) and reagent-2 (R2) $1.0 \mathrm{~mL}$ were used as for blank, standard and samples of serum too. Solutions were mixed and left within the room temperature for 10 minutes. The estimation was then performed via reading the absorption spectrum for the sample and the standard solution at a wave length $550 \mathrm{~nm}$ 
while the device was labeled using an efficient solution.

\subsection{Separation and Purification of Gama-Glutamyl Transfrase (GGT) from Sera of Patients with Cardiac Disorders and Healthy (Control)}

Purification of GGT enzyme was performed according to the following procedures:

\subsection{Deposition by Ammonium Sulphates}

Precipitation by Ammonium Sulphate: The blood proteins were deposited with ammonium sulphate by $60 \%$ by adding $3 \mathrm{gm}$ of ammonium Sulphate to $5 \mathrm{~mL}$ of blood serum during 45 - 60 minutes and placing the serum in the ice with constant stirring. The precipitant was then dissolved by $5 \mathrm{~mL}$ of $0.125 \mathrm{M} \mathrm{HCl}$-Tris with a $\mathrm{pH} 8.3$.

\subsection{The GGT Enzyme Was Purified Using the Following Steps}

In order to remove the remaining Ammonium Sulfate from the protein deposition, the dissolved protein is placed, from the above step, in membrane of the dialysis bag following measuring the activity of the GGT and protein concentration, and immersing the sachet in the structured solution (HCl-Tris $0.125 \mathrm{M}$ ) of $\mathrm{pH}$ 8.3. The solution is changed from time to time for a whole night. This step is carried out at $4^{\circ} \mathrm{C}$ to maintain GGT activity. After the membrane separation was completed, the GGT and protein concentration were measured according to method adopted by Owen and Redfield (2005) [20].

\subsection{Concentration of Dissolved Protein}

The dissolved protein was deposited in the membrane separation bag and dipped in sucrose crystals for $30-45$ minutes at $4^{\circ} \mathrm{C}$.

\subsection{Gel Filtration}

This method is based on the difference in molecular weight which is used as an initial step to partially eliminate the salts and proteins associated with the enzyme. The filter column of the Sephadex G150 was used. Ion exchange chromatography was used via DEAE-Cellulose A50 resin column to purify GGT from the central protease and separate its isomers.

\subsection{Electrolysis of Acryl Gel with Ammid Presence of SDS}

Sodium Dodecyl Sulfate-Polyacryl Amide GelElectrophoresis (SDS-PAGE) The Laemmli method [21] was used in the preparation of electrolyte separation gel with some modifications using $10 \%$ acryl-amide gel and Coomassie brilliant blue.

\section{Results}

\section{1) Estimation of GGT activity in serum:}

The arithmetic means of general GGT activity in the sera of the heart failure 
patients were significantly $(p \leq 0.01)$ higher i.e. almost five folds $(66.9 \pm 17 \mathrm{U} / \mathrm{L})$ than those of control $(12.07 \pm 0.6 \mathrm{U} / \mathrm{L})$. The activity of the enzyme GGT in the male HF patients displayed significantly $(p \leq 0.01)$ higher records than those of female patients in comparison with their counter control. Simultaneously, a significant difference $(p \leq 0.01)$ in the activity of the enzyme GGT in the male HF patients sera was also noticeably higher in patients aged above forty years old in comparison with those of below 40 years old which overlapped between the genders in comparison with the control (Table 1). The results showed significant differences between patients and healthy control as well as significant differences between the age groups of patients at $p \leq 0.01$ in comparison with healthy control. The levels of GGT have been proportional with both severity of the disease and with age.

\section{2) Effects of electrolytes:}

The arithmetic means in the levels of electrolytes Sodium, Potassium and Chlorine $\left(\mathrm{Na}^{+1} ; \mathrm{K}^{+1}\right.$ and $\left.\mathrm{Cl}^{-1}\right)$, respectively measured in $\mathrm{m} . \mathrm{mol} / \mathrm{L}$ in the sera of $\mathrm{HF}$ patients and their counter parts control as showed an insignificant difference in the level of Sodium ions between the males and females whereas a significant difference $(p \leq 0.01)$ was seen in Potassium ions in the males only. However, both males and females showed significant differences $(p \leq 0.05)$ in Chlorine ions (Table 2).

\section{3) Partial purification of GGT enzyme of HF patients:}

Using 60\% Ammonium Sulphate and after obtaining the required purity, the

Table 1. The activity rate of GGT (iU/L) in both male and female HF patients for ages less and more than 40 years old. Student-T test showed the difference in the rate of GGT in $\mathrm{iU} / \mathrm{L}$ of $\mathrm{HF}$ patients in comparison with the control is significant $\left.(p \leq 0.01){ }^{*}\right]$. (n) number of patients and control encountered.

\begin{tabular}{cccc}
\hline Age $($ years $)$ & GGT iU/L & GGT iU/L Control & $p($ Student - Test $)$ \\
\hline$<40$ Male $(\mathrm{n}=17)$ & $43.64 \pm 1.4^{*}$ & $5.70 \pm 0.68$ & $p \leq 0.01$ \\
$>40$ Male $(\mathrm{n}=53)$ & $67.56 \pm 1.5^{*}$ & $11.36 \pm 0.12$ & $p \leq 0.01$ \\
$<40$ Female $(\mathrm{n}=6)$ & $37.82 \pm 0.87^{*}$ & $7.11 \pm 0.86$ & $p \leq 0.01$ \\
$>40$ Female $(\mathrm{n}=44)$ & $57.82 \pm 2.0^{*}$ & $14.75 \pm 0.76$ & $p \leq 0.01$
\end{tabular}

Table 2. Mean levels and standard deviation ( \pm sd) of three electrolytes $\left(\mathrm{Na}^{+1} ; \mathrm{K}^{+1}\right.$ and $\left.\mathrm{Cl}^{-1}\right) \mathrm{mmol} / \mathrm{L}$ activity, respectively in the sera of HF patients in comparison with the control. (n) number of patients and control involved; $(p)$ Student T-test; $\left.{ }^{*}\right]$ significant difference.

\begin{tabular}{cccc}
\hline Individuals & $\mathrm{Na}^{+1}$ & $\mathrm{~K}^{+1}$ & $\mathrm{Cl}^{-1}$ \\
\hline Male $[\mathrm{HF}](\mathrm{n}=70)$ & $136.2 \pm 0.86$ & $5.07 \pm 0.1^{*}$ & $196 \pm 50^{*}$ \\
Female $[\mathrm{HF}](\mathrm{n}=50)$ & $136.3 \pm 1.8$ & $3.85 \pm 0.09$ & $319 \pm 72^{\star}$ \\
Male control $(\mathrm{n}=45)$ & $140 \pm 12.5$ & $4.2 \pm 1.2$ & $109 \pm 11.0$ \\
Female $(\mathrm{n}=35)$ & $148 \pm 4.4$ & $4.0 \pm 0.9$ & $227 \pm 43$ \\
$p($ Student-Test $)$ & $p \geq 0.05$ & $p \leq 0.01$ & $p \leq 0.05$ \\
\hline
\end{tabular}


excess salt was eliminated by membrane separation dialysis via $0.125 \mathrm{M}$ Tris$\mathrm{HCl}$ at $\mathrm{pH}$ 8.3. The degree of purification of the iso-enzyme-I obtained was 3.3 folds higher with the enzyme yield of $37.6 \%$. A single peak was obtained with a purity of up to 5 fods with an enzyme yield of $47.3 \%$ by chromatography of gelatin filtration the gaseous Sephadex G-150 (Table 3). A single peak was obtained (Figure 1) with purity of 3.65 times and enzymatic purity of $47.3 \%$. In order to complete the subsequent purification stages, the GGT isomers were separated by ion exchange chromatography using the DEAE-Cellulose A50 resin as a column filler and a graduated solution of sodium chloride. Ion exchange chromatography method was used to separate and purify the enzymes that are based on the principle of verified charges of the isomers with the corresponding purity of (5.24) times, as shown in Table 3.

With the electrode separation method (SDS-PAGE gel) at a concentration of $10 \%$ with CBB R250 dye, two bands appeared separated from the GGT were expressed in the ion exchange method (Figure 2). The location of these packages refers to the molecular weight of these isomers as $68 \mathrm{KDa}$. The enzyme carries a negative charge as it is attracted to the positive electrode leading to move the protein in the gel accordingly.

Table 3. Separation and purification of the GGT enzyme from heart failure patients.

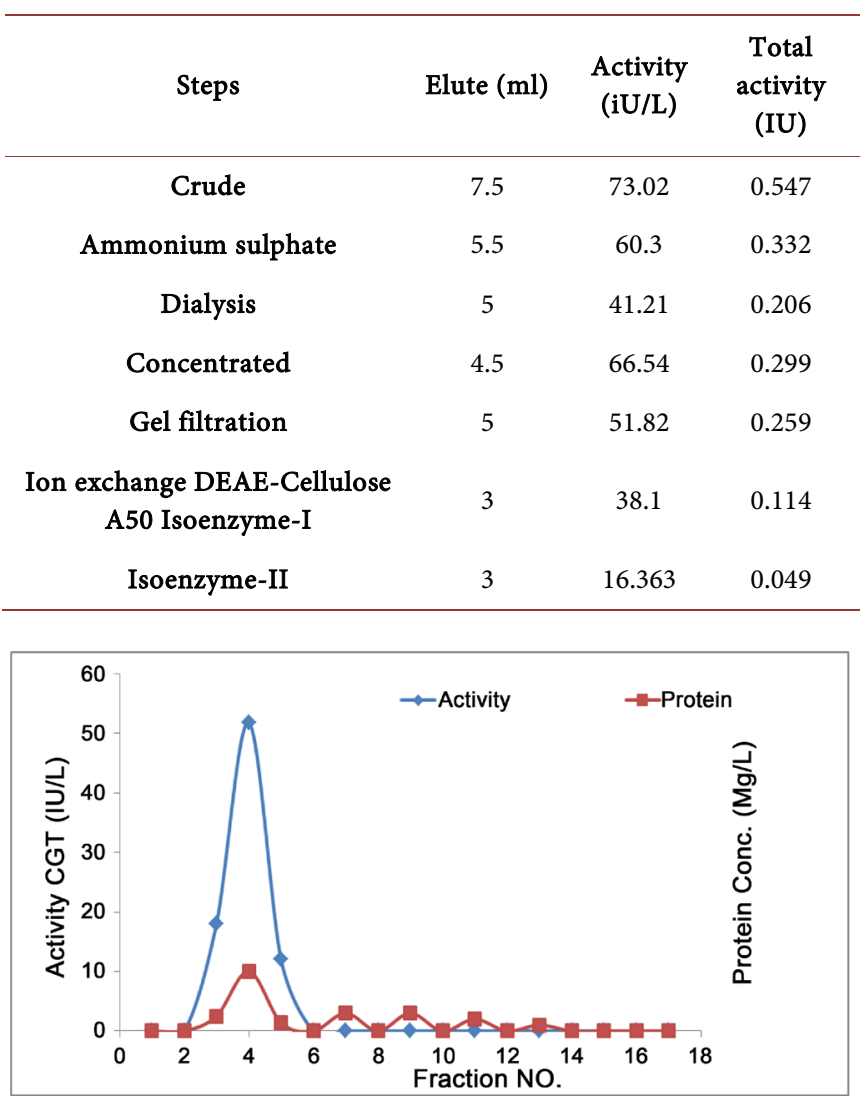

(a)

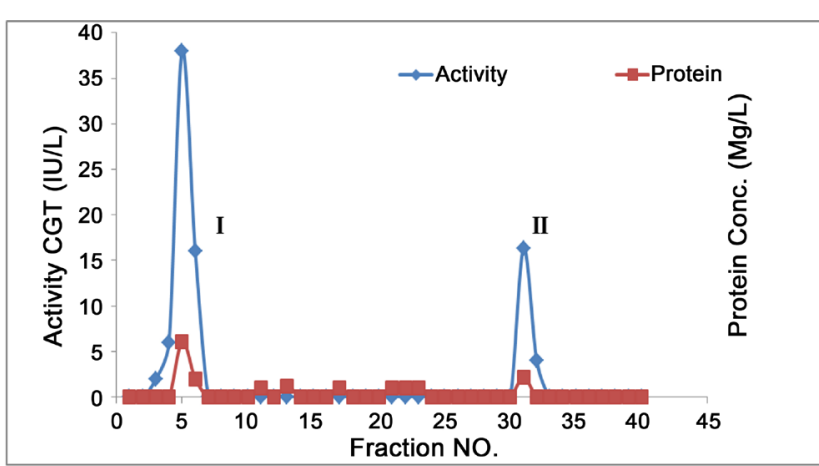

(b)

Figure 1. (a) Purification of the enzyme GGT from sera of HF patients using chromatography gelatin filtration G-150 Sephadex; and (b) Isolation of isoenzyme GGT from HF patients using ionic A50 cellulose-DEAE change chromatography. 


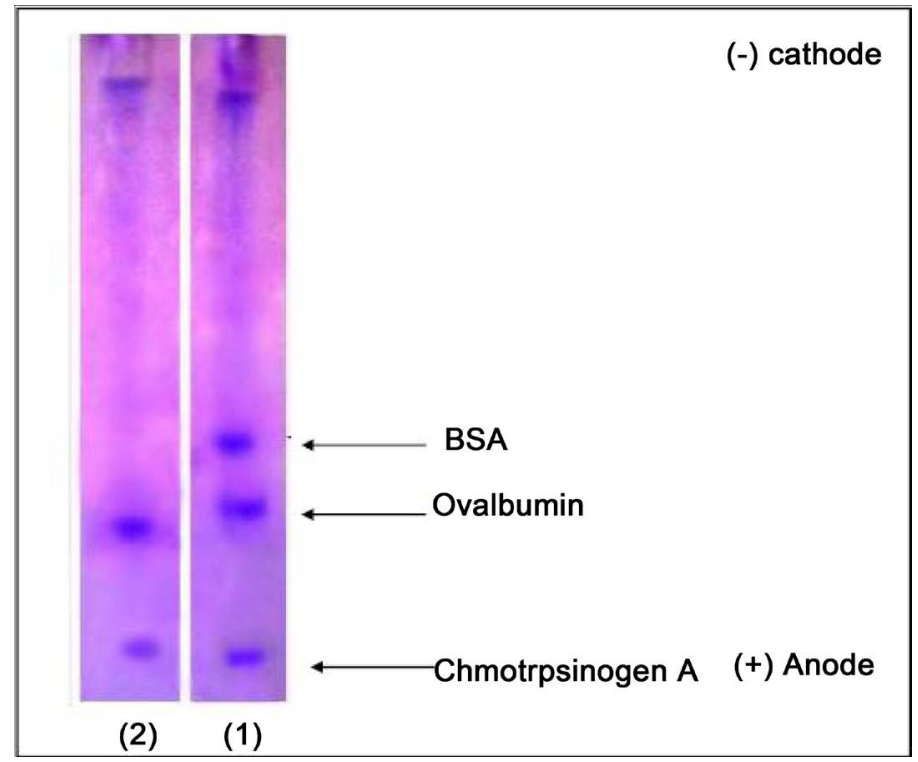

Figure 2. Electro-gel separation of the enzyme GGT from the sera of the HF patients.

\section{4) Kinetic studies of the partially purified GGT isoenzyme-I:}

Optimum substrate concentration and $\mathrm{Km}$ : The concentration of the basic materials was studied against the reaction speed of GGT iso-enzyme-I partially separated from the ionic exchange column until the ideal concentration [2 $\mathrm{mM}$ ] (Figure 3(a) \& Figure 3(b)), respectively. The speed then started to reduce at higher concentrations due to the inhibition. The iso-enzymes appear to be subject to the equation of Michaelis-Menten plot.

Another method, Lineweaver-Burk, linear equation was used to calculate the values of $\mathrm{Km}$ as it was $1.66 \mathrm{mM}$ and the value of $\operatorname{Vmax}(24 \mathrm{mM} / \mathrm{min})$ from the isoenzyme-I for HF patients. However, in control these values were $0.4 \mathrm{Km}(\mathrm{mM})$ and the Vmax was $7.2 \mathrm{mM} / \mathrm{min}$ (Figure 4(a) \& Figure 4(b)).

\section{5) The effect of $\mathrm{pH}$ over the reaction speed of the purified iso-enzyme-I:}

Using various levels of $\mathrm{H}^{+}$in the working isotonic solution used in the reaction of GGT iso-enzyme-I leads to raise in the reaction velocity with the raise of $\mathrm{H}+$ up to the maximum speed at the ideal $\mathrm{pH}, 8.3$ where it reaction of isoenzyme will go down accordingly. Figure 5(a) and Figure 5(b) demonstrate the relation of reaction speed and the various levels of $\mathrm{H}^{+}$isomers in both control and those in HF patients.

6) The effects of reaction time on the activity of the iso-enzyme-I (Optimum time):

The reaction time of the purified GGT iso-enzyme-I isolated from the sera of the HF patients was evaluated against the activity using $2 \mathrm{mM}$ of the basic GPNA for various time schedules $(5,10,15,20,25,30,35,40,45$ and $50 \mathrm{mi}-$ nutes) and at $37^{\circ} \mathrm{C}$ and $\mathrm{pH}$ 8.3. The activity of the enzyme raised in both cases the clinical and the normal and a maximum activity of the enzyme was at $5 \mathrm{mi}$ nutes when the activity began to decrease as in Figure 6(a) and Figure 6(b) respectively. 


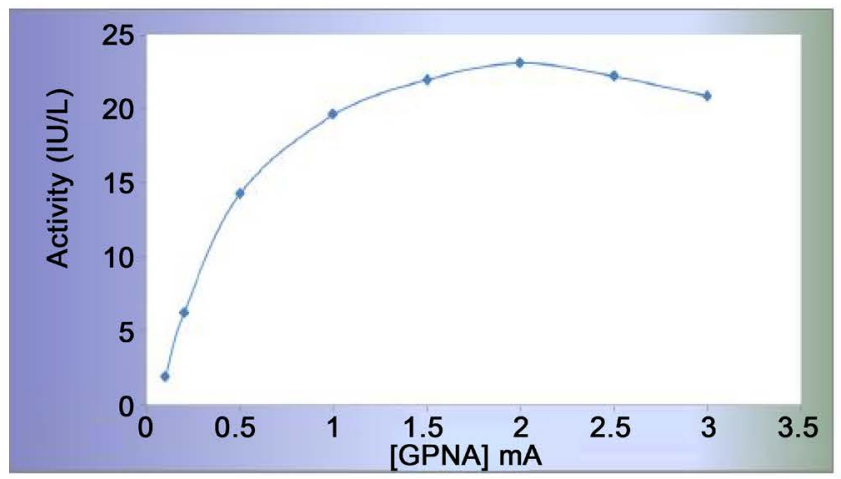

(a)

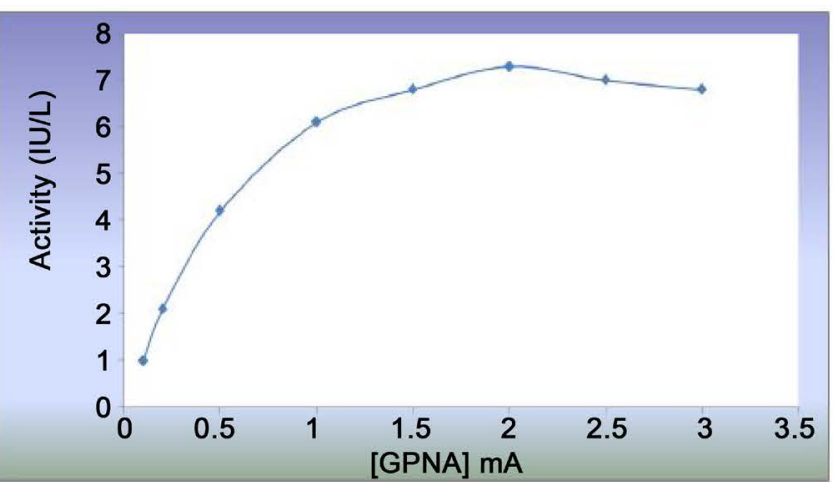

(b)

Figure 3. Demonstrates the effect of the principle material on iso-enzyme-I GGT in (a). HF patients and (b). In control.

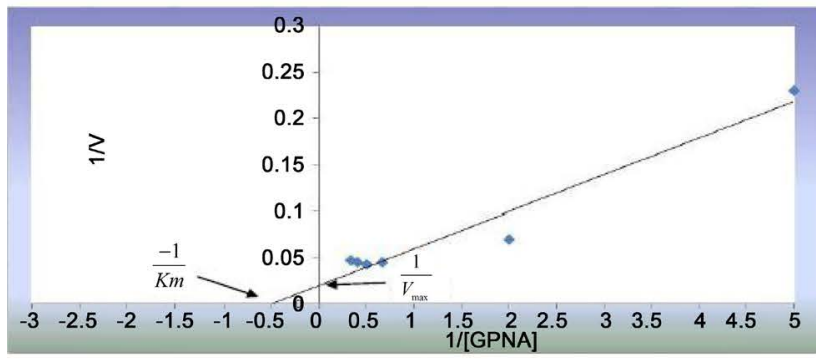

(a)

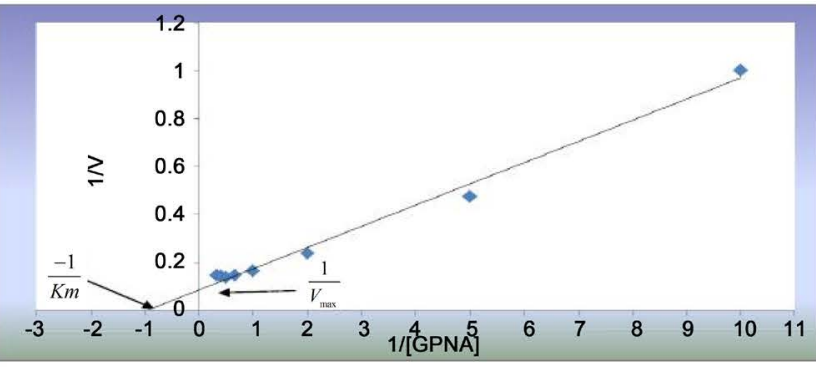

(b)

Figure 4. Lineweaver and Burk plot to demonstrate the purified iso-enzyme GGT in Km (a) in HF patients and (b) in control.

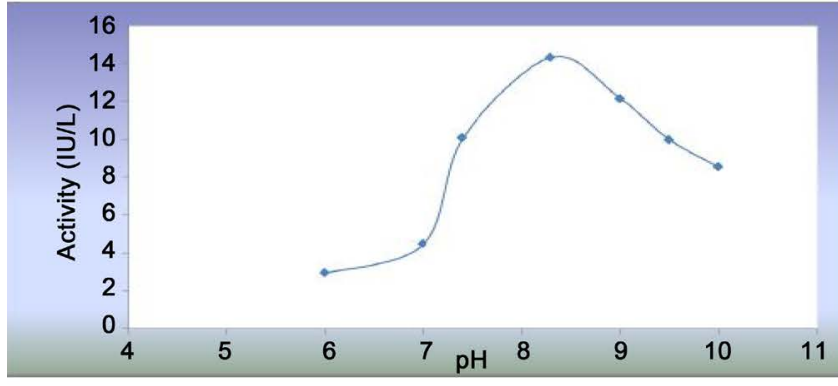

(a)

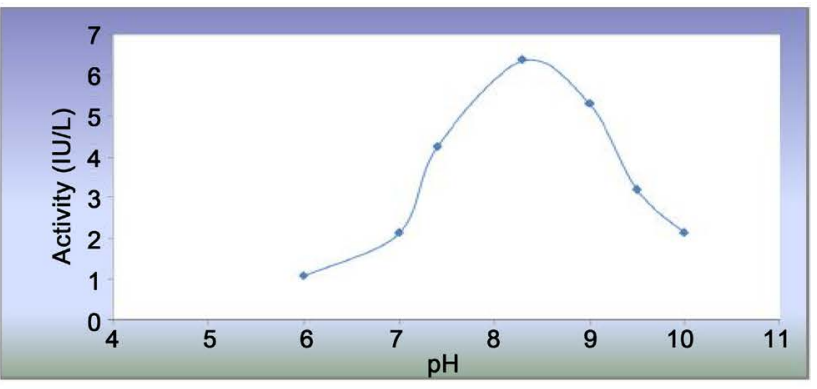

(b)

Figure 5. The effect of the $\mathrm{pH}$ on the activity of the purified iso-enzyme-I GGT from (a) HF patients and (b) Control.

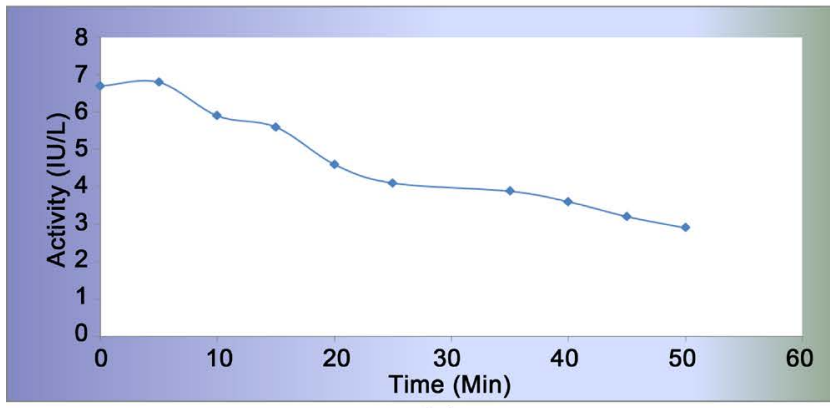

(a)

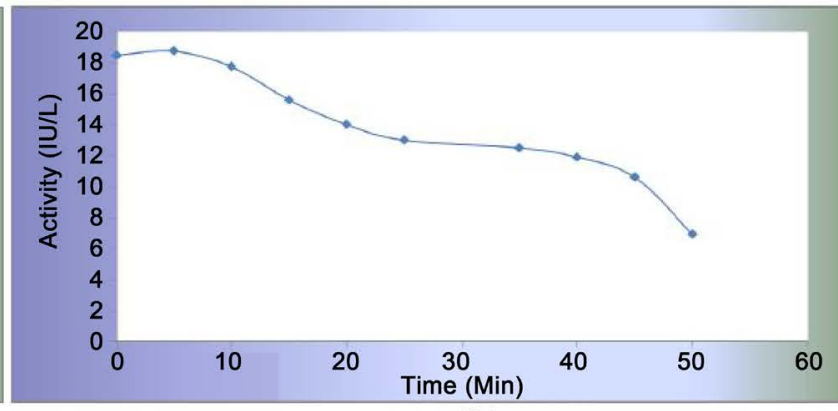

(b)

Figure 6. The effects of time on the activity of the purified iso-enzyme-I GGT from (a) HF patients and (b) Control. 
7) The effect of temperature on the activity of the iso-enzyme-I (Optimum temperature):

The results showed a high reaction rate for the iso-enzyme-I of the GGT purified sera of both HF patients and the healthy with the increase in temperature and a maximum temperature of $37^{\circ} \mathrm{C}$ (Figure 7(a) and Figure 7(b)).

\section{8) Effect of Amino Acids and Glutathione on iso-enzyme-I Purified from}

\section{Serum:}

The effect of some amino acids against the speed of the isoenzyme-I reaction of GGT purified from the sera of HF patients was assessed. The amino acids Glutathione, Arginine and Glycine with concentrations i.e. 0.5, 1, 2, 4, and 10 $\mathrm{mM}$ showed varying degrees of inhibition against the isoenzyme-I. The maximum degree of inhibition was found at $10 \mathrm{mM}$ concentration by an inhibition ratio $(71.4 \%, 72.7 \%$ and $63.6 \%)$ (Table 4$)$.

To identify and determine the type of inhibition caused by the glutathionine, arginine and glycine of the purified iso-enzyme-I of HF patients various concentrates of these three amino acids were used with different substrates of GPNA. The results using Dixon drawing are illustrates in Figures 8(a)-(c) where the plot of the relationship between $1 / \mathrm{v}$ versus the inhibitory concentration.

\section{9) The effects of drugs on iso-enzyme-I purified from sera of HF patients.}

The effect of some chemicals on the reaction speed of the purified GGT isoenzyme-I from the HF patients using Aspirin, Digoxin in several concentrates i.e. $(0.5,1,2,4$, and $10 \mathrm{mM})$. There has been varying levels of inhibition in the iso-enzyme-I with a maximum inhibition at $10 \mathrm{mM}$ of $54.5 \%$ for Digoxin $45.5 \%$ for asperine (Table 5).

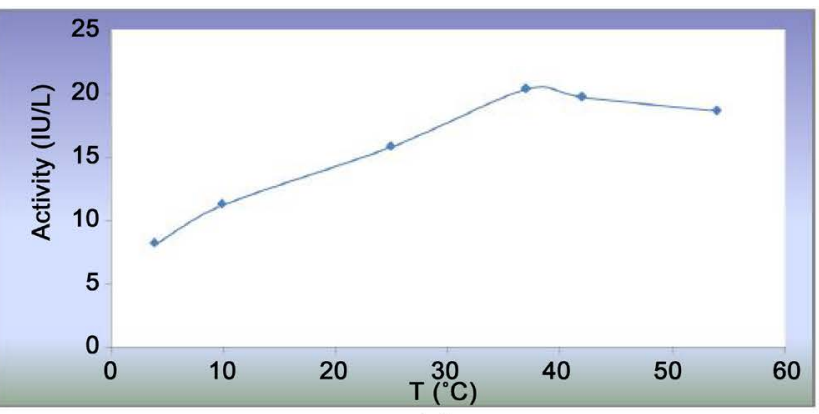

(a)

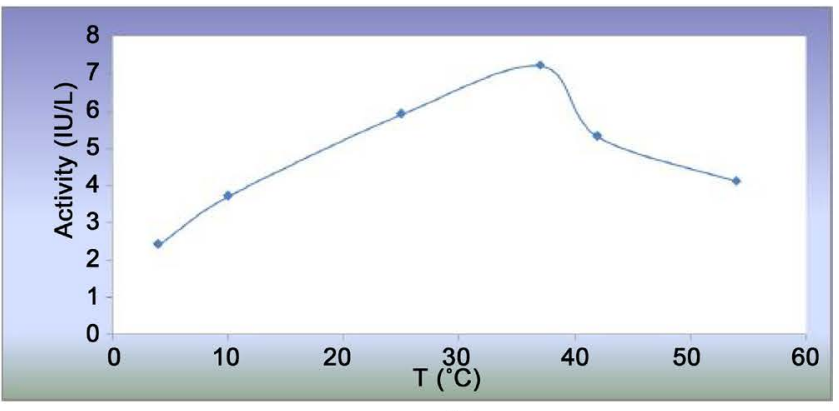

(b)

Figure 7. The effect of temperature $\left({ }^{\circ} \mathrm{C}\right)$ on the activity of the purified iso-enzyme-I GGT from. HF patients and Control, respectively.

Table 4. The inhibition proportion represented as arithmetic means of the three amino acids Glutathione, Arginine and Glycine using various concentrations of the iso-enzyme-I in HF patients and \pm SD.

\begin{tabular}{cccccc}
\hline \multirow{2}{*}{ Amino acids } & \multicolumn{5}{c}{ Inhibition rate\% } \\
\cline { 2 - 6 } & $\mathbf{0 . 5} \mathrm{mM}$ & $\mathbf{1 ~} \mathbf{~ M}$ & $\mathbf{2 ~ m M}$ & $\mathbf{5 ~ m M}$ & $\mathbf{1 0 ~} \mathbf{m M}$ \\
\hline Glutathione & $36.4 \pm 4.5$ & $45.4 \pm 5.6$ & $54.5 \pm 8.8$ & $63.6 \pm 6.7$ & $72.7 \pm 9.6$ \\
Arginine & $27.3 \pm 3.3$ & $36.4 \pm 4.3$ & $45.5 \pm 2.1$ & $54.5 \pm 7.0$ & $63.6 \pm 9.1$ \\
Glycine & $14.3 \pm 3.1$ & $28.6 \pm 6.0$ & $42.8 \pm 4.9$ & $57.1 \pm 6.2$ & $71.4 \pm 12.0$ \\
\hline
\end{tabular}




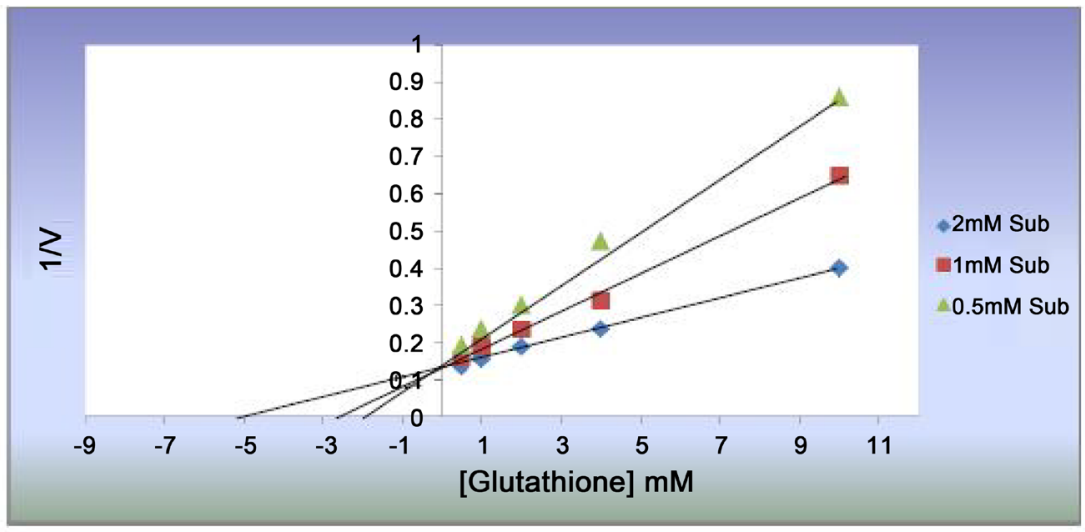

(a)

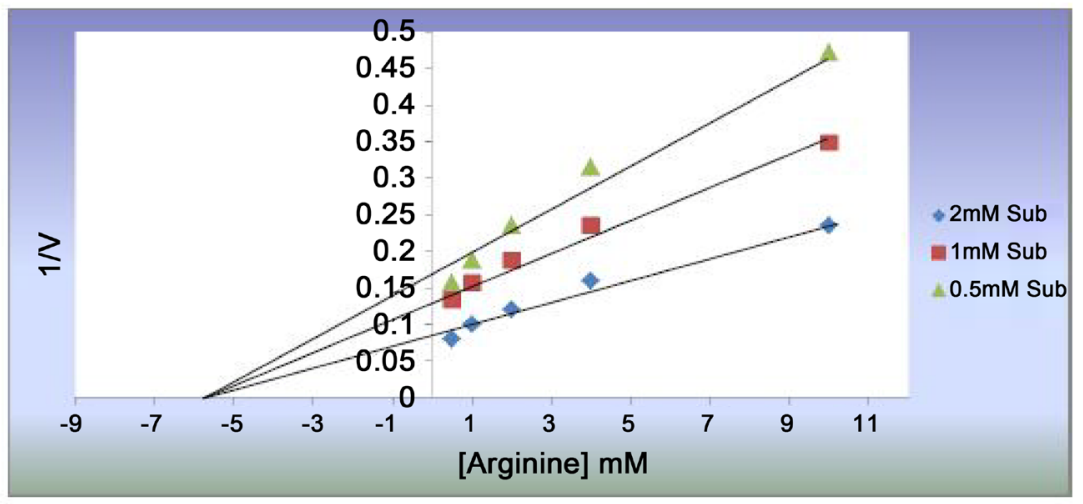

(b)

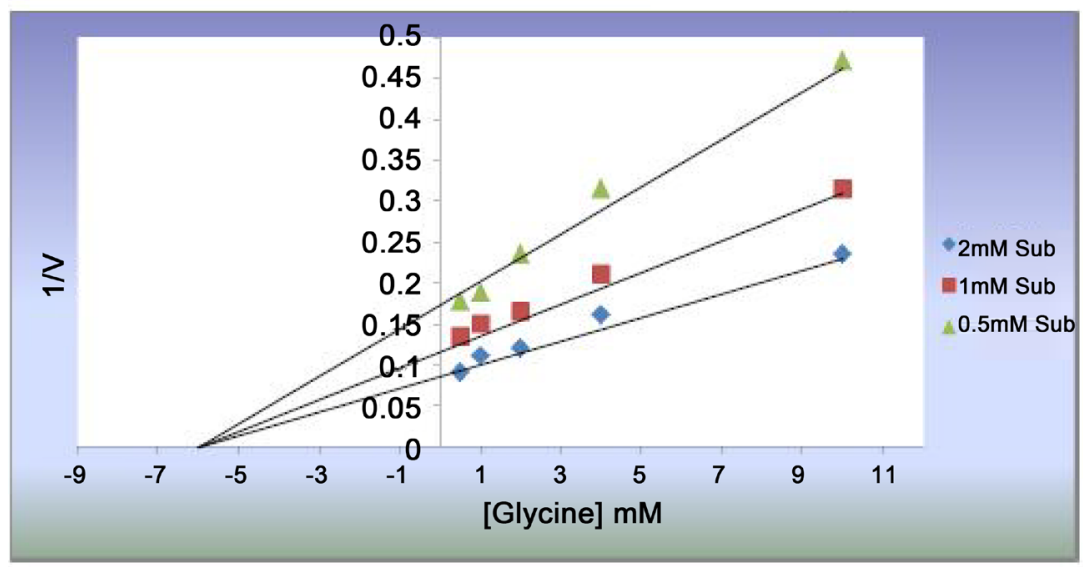

(c)

Figure 8. The inhibition effects of Glutathione (a); Arginine (b); and Glysine (c) on the sera of HF patients.

Table 5. The effects of two different drugs, Digoxin and Aspirin on inhibition proportion of various concentrations of iso-enzyme-I of the HF patients.

\begin{tabular}{cccccc}
\hline \multirow{2}{*}{ Drugs } & \multicolumn{5}{c}{ Inhibition\% } \\
\cline { 2 - 6 } & $0.5 \mathrm{mM}$ & $1 \mathrm{mM}$ & $2 \mathrm{mM}$ & $4 \mathrm{mM}$ & $10 \mathrm{mM}$ \\
\hline Digoxin & 18.2 & 27.3 & 36.3 & 45.45 & 54.5 \\
Aspirin & 9.1 & 18.2 & 27.3 & 36.4 & 45.5 \\
\hline
\end{tabular}




\section{Discussion}

A total of 200 patients encountered, in this research, would benefit to provide a robust source of data for the reliability of the biostatistics and the conclusion. Accordingly, the five folds increase in the rate of GGT in heart failure (HF) patients in comparison with the control indicates an unbiased significant difference, at the absence of any other factors which may interfere to influence the elevation of GGT readings. The general results in this research are in agreement with most recent works and could favor in predicting the possibility of mortality in heart failure, cardiac and visceral disorders of elderly people [22] [23] [24] [25] [26]. An elevation of GGT activity is seen in all forms of liver disease particularly in intra- or post-hepatic bill obstruction [27]. High levels of the enzyme GGT detected has been an early forecast for development of a premature arteriosclerosis and other cardiovascular diseases, i.e. myocardial infarction, heart failure, stroke, and diabetes, as well as increase the enzyme level in cases of triglycerides high cholesterol liver disease and excessive alcohol consumption factor [24] [25] [28]-[37]. The activity of GGT in this study in male HF patients was higher than those of female in comparison with their counterpart control. This result is in concomitant with other recent studies [24] [36] [37]. The gender variation of GGT levels could be attributed to female hormones and the nature of myocardiocytes, which are more resistant to cell death. The latter is controlled by estrogen hormone, which induces the cardiac system and blood vessels to increase resistance to the cell death while $5 \%$ of proteins produced by myocardiocytes are controlled by estrogen [38] [39] [40]. Hence, the significant age-relevant increase in the GGT levels of the HF patients is likely to be proportional with the severity of the disease and the senility.

Various experiments carried out in the present study targeted to explore a clear understanding the role GGT in HF patients. Electrolyte is an important role in controlling various physiological activities as ions within the body liquids. The Sodium ions form almost $2 \%$ of the body fluids while the Potassium $5 \%$ and the chloride $3 \%$ of the total elements present in the body liquids. Both $\mathrm{Na}^{+}$and $\mathrm{Cl}^{-}$exist together in cellular fluids, while $\mathrm{K}^{+}$is the primary constituent of cells [41] (role in neurotransmission and cell growth and it is a catalyst for many enzymes [42] [43]). The increase in potassium indicates stress in the function of kidney and reduction in the glomerular filtration rate (GFR) [44] [45] [46]. This could be attributed to the poor circulatory system course failure in fluid discharge from the body in patients suffering accumulation of body fluids. The latter leads to low cardiac output, increased central venous pressure, and increase in venous renal pressure. As a consequence, the pressure of GFR will decrease down [47]. The results showed a significant increase Chloride concentration in both genders in comparison with counter control as the Chloride exist mainly at the extra cellular matrix (ECM) [41]. This could be attributed to the metabolic acidosis, which leads to increase its concentration in the blood [48]. The latter is followed by the size and shape of the protein as the enzyme protein 
migrated to the $\mathrm{pH}$ number 8.3 within the electric field between the positive and negative electrode depending on the factors mentioned. Previous literatures indicated that GGT has been purified from Helicobacter pylori bacteria from the mucosa of stomach [49] and the bacteria Escherichia coli K-12 from human neutrophils [50] [51], human liver [52], pig kidney [53], onion [54], however, there is no evidence to refer to the purification of iso-enzyme of GGT in the serum of patients with heart failure. The molecular weight of $68 \mathrm{KDa}$ found in this study is consistent with the previous researches [55] [56] [57] [58]. It carries a negative charge and will be attracted to the positive electrode as the movement of the protein depends on the main charge, the size and shape of the protein, altered so that the protein of the enzyme has been fermented in a pH 8.3 [59] [60]. Using the basic substance Gamma Glutamyl-p-nitroanilide (GPNA) the result is concomitant with results obtained from pig's kidney (1.87) [53] [61]. The Km value extracted from bacteria was $1.06 \mathrm{mM}$, respectively [49]. The $\mathrm{Km}$ of the enzyme GGT in human varied within organs i.e. $0.7 \mathrm{mM}$ in pancreas, $0.91 \mathrm{mM}$ in the duodenum [52], while the Km value of the purified GGT extracted from the human neutrophils had $1.8 \mathrm{mM}$ [51]. No previous record is found so far in previous works concerning the kinetic of the purified GGT from the HF patients.

The $\mathrm{pH}$ can affect the enzyme activity due to the variation in its nature and chemical structure as well as the presence of various ionic groups which the enzyme carries [62]. All enzymes work at an ideal $\mathrm{pH}$ leading to change in the concentration of $\mathrm{H}^{+}$ion [63]. Any change in the $\mathrm{H}^{+}$leads to the reduction in the enzymes activity [64] as the enzyme posses a complicated three dimension configuration which plays a role in the establishment and action of active site of the enzyme. Any change in the hydrogen ion $\mathrm{H}^{+}$could, accordingly, lead to the removal of the natural configuration of the enzyme (or denaturation) of the enzyme due to changing in the ionization status of the amino acids at the active site of the enzyme, as a consequence to loss of enzyme activity [64]. Our result is in concomitant with a most recent work on human Neutrophils [51] and Helicobacter pylori in intestinal mucosa of human [49]. It could be attributed to the nature of the enzyme itself as the bonds break down by the time passed between each pair of amino acids.

The enzymes posses an optimal temperature with a little variation $[ \pm]$ from the temperature of the cell which they are existed in and the reaction speed is proportional with the temperature up to an optimal temperature when it gradually comes down. The latter is attributed to the gradual mutilated enzyme molecules which decrease or demolish the enzyme molecule where it works due to the reduction or loss of enzyme efficacy. This reduction is facilitated by the effect of high temperature on to the ionization of the aggregates present on the surface of the enzyme and on the basic components. Therefore, any increase in the temperature leads to alterations in the enzyme's natural and shape, causing loss of enzyme activity. The high temperature levels increase the kinetic energy which 
break, in turn, the bond between active amino acids, causing loss of enzyme activity [65]. None of above literatures tackled the kinetic of the enzyme in the hemorrhage of HF patients.

The glutathione acts as a competitive inhibitor as the $\mathrm{Km}$ increases while the maximum velocity ( $\operatorname{Vmax}$ ) remains consistent with the increasing concentration of competitive inhibitor. Accordingly, it could be possible to inhibit this type of inhibition by increasing the concentration of the base material. Such result is in concomitant with other studies [65]. However, with arginine and glycine they act as non-competitive inhibitors where $\mathrm{Km}$ remains constant while the maximum velocity $(V \max )$ is reduced on the assumption that the basic material has the same tendency to correlate with each of the free enzyme-E and the inhibitory enzyme, while no evidence of GGT inhibition was ever tackled in other literatures [66]. The goal of purification has been to identify the GGT iso-enzymes in order to obtain the $\mathrm{Km}$ and Vmax for each iso-enzyme for comparative purpose as a tool to diagnose the HF status.

Finally, the capacity and a consequence response of an individual to any change in the mechanics of action of a drug is an important factor in the drug interactions. Many drugs can cause various mechanical effects to the physiology of the body as a drug may act on a single or multiple receptors or may affect site-links of some receptors, as well as competition in the link mechanism towards the same location or adversely. The latter could either be competitive or non-competitive [67]. These pharmacokinetics interactions can affect the distribution of different mechanism i.e. absorption, transport, metabolism or distribution of drugs as some drugs may also activate or inhibit the enzymes, which play a role in the cellular metabolism i.e. the effect of the drug on human liver enzymes [68].

In order to obtain a high level of purification, the proteins could usually be concentrated during the first purification stages of the enzymes by removing a big deal of water from it. Salts, such as ammonium sulphates, are often used for this purpose due to their good solubility in water. Precipitation takes place via salts as a result of equilibrium of protein ions by the action of salt leading to decrease in solubility of protein which the process called salting outside (Salting out) [69]. The mechanism of elevation of the GGT in heart failure victims is not clear enough at this stage but is most likely that it is due to its effects on cardiac muscle rhythm and capacity.

It is concluded that the GPs may also order the GGT test as a direct tool to prognosis the early HF condition in patients suffering from cardiac muscle disorders.

\section{References}

[1] Whitfield, J.B. (2001) Gamma Glutamyl Transferase. Critical Reviews in Clinical Laboratory Sciences, 38, 263-355. https://doi.org/10.1080/20014091084227

[2] Guyton, A.C. and Hall, J.E. (2006) Text Book of Medical Physiology. 11th Edition, Elsevier Saunders, Philadelphia, p. 188. 
[3] Nadji, G., Rusinaru, D., Rémadi, J.P., Jeu, A., Sorel, C. and Tribouilloy, C. (2009) Heart Failure in Left-Sided Native Valve Infective Endocarditis: Characteristics, Prognosis, and Results of Surgical Treatment. European Journal of Heart Failure, 11, 668-675. https://doi.org/10.1093/eurjhf/hfp077

[4] Tate, S.S. and Meister, A. (1985) Gamma-Glutamyl Transpeptidase from Kidney. Methods in Enzymology, 113, 400-419. https://doi.org/10.1016/S0076-6879(85)13053-3

[5] Dominici, S., Paolicchi, A., Corti, A., Maellaro, E. and Pompella, A. (2005) Prooxidant Reactions Promoted by Soluble and Cell-Bound Gamma-Glutamyltransferase Activity. Methods in Enzymology, 401, 484-501. https://doi.org/10.1016/S0076-6879(05)01029-3

[6] Figueroa, M.D. and Peters, J.I. (2006) Congestive Heart Failure: Diagnosis, Pathophysiology; Therapy and Implications for Respiratory Care. Respiratory Care, 51, 403-412.

[7] Dixon, J.A. and Spinale, F.G. (2009) Large Animal Models of Heart Failure: A Critical Link in the Translation of Basic Science to Clinical Practice. Circulation: Heart Failure, 2, 262-271. https://doi.org/10.1161/CIRCHEARTFAILURE.108.814459

[8] Gaasch, W.H. and Zile, M.R. (2004) Left Ventricular Diastolic Dysfunction and Diastolic Heart Failure. Annual Review of Medicine, 55, 373-394. https://doi.org/10.1146/annurev.med.55.091902.104417

[9] Lum, G. and Gambino, S.R. (1972) Serum Gamma-Glutamyl Transpeptidase Activity as an Indicator of Disease of Liver, Pancreas, or Bone. Clinical Chemistry, 18, 358-362.

[10] Dienstag, J.L. (2015) Chapter 362: Chronic Hepatitis. In: Kasper, D., Fauci, A., Hauser, S., Longo, D., Jameson, J. and Loscalzo, J., Eds., Harrison's Principles of Internal Medicine, 19th Edition, McGraw-Hill, New York.

[11] Kumar, V., Abbas, A.K., Fausto, N., Robbins, S.L. and Cotran, R.S. (2005) Robbins and Cotran Pathologic Basis of Disease. 7th Edition, Elsevier Saunders, Philadelphia.

[12] Li, C.-C., Lii, C.-K., Liu, K.-L., Yang, J.-J. and Chen, H.-W. (2007) DHA Down-Regulates Phenobarbital-Induced Cytochrome P450 2B1 Gene Expression in Rat Primary Hepatocytes by Attenuating CAR Translocation. Toxicology and Applied Pharmacology, 225, 329-336.

[13] Araya, M., Chen, B., Klevay, L.M., Strain, J.J., Johnson, L., Robson, P., Shi, W., Nielsen, F., Zhu, H., Olivares, M., Pizarro, F. and Haber, L.T. (2003) Confirmation of an Acute No-Observed-Adverse-Effect and Low-Observed-Adverse-Effect Level for Copper in Bottled Drinking Water in a Multi-Site International Study. Regulatory Toxicology and Pharmacology, 38, 389-399.

[14] https://labtestsonline.org/understanding/analytes/ggt/tab/test/

[15] Willard \& Spackman's Occupational Therapy (2014) Philadelphia: Wolters Kluwer Health/Lippincott Williams \& Wilkins. 12th Edition, 1124.

[16] Wier, L.M., Hao, Y., Owens, P. and Washington, R. (2013) Overview of Children in the Emergency Department, HCUP Statistical Brief 157. Agency for Healthcare Research and Quality, Rockville.

[17] Chronic Heart Failure: National Clinical Guideline for Diagnosis and Management in Primary and Secondary Care: Partial Update. National Clinical Guideline Centre: 71-153. https://en.wikipedia.org/wiki/Heart_failure

[18] Michael, R.Z. (2005) Treating Diastolic Heart Failure with Statins. Circulation, 112, 300-303. https://doi.org/10.1161/CIRCULATIONAHA.105.551887 
[19] Adelino, F. and Leite-Moreior (2006) Current Perspectives in Diastolic Dysfunction and Diastolic Heart Failure. Heart, 92, 712-718. https://doi.org/10.1136/hrt.2005.062950

[20] Owen, T.E. and Redfield, M.M. (2005) Epidemiology of Diastolic Heart Failure. Progress in Cardiovascular Diseases, 47, 320-332.

[21] John, J.V., Stamatis, A., Stefan, D.A., Angelo, A., Michael, B., Kenneth, D., et al. (2012) ESC Guidelines for the Diagnosis and Treatment of Acute and Chronic Heart Failure 2012. European Heart Journal, 33, 1787-1847. https://doi.org/10.1093/eurheartj/ehs104

[22] Lee, D.H., Silventoinen, K., Hu, G., Jacobs, D.R., Jousilahti, P., Sundvall, J. and Tuomilehto, J. (2006) Serum Gamma-Glutamyl Transferase Predicts Non-Fetal Myocardial Infarction and Fetal Coronary Heart Disease among 28,838 Middle-Aged Men and Women. European Heart Journal, 27, 2170-2176.

[23] Poelzl, G., Eberl, C., Achrainer, H., Doerler, J., Pachinger, O., Frick, M., et al. (2009) Prevalence and Prognostic Significance of Elevated Gammaglutamyl Transferase in Chronic Heart Failure. Circulation: Heart Failure, 2, 294-302. https://doi.org/10.1161/CIRCHEARTFAILURE.108.826735

[24] Ravi, D., Philimon, G.P., Thomas, J.W., Caroline, S.F. and Ramachandran, S.V. (2010) Serum Gamma Glutamyl Transferase and Risk of Heart Failure in the Community. Arteriosclerosis, Thrombosis, and Vascular Biology, 30, 1855-1860. https://doi.org/10.1161/ATVBAHA.110.207340

[25] Lee, D.H., Buijsse, B., Steffen, L., Holtzman, J., Luepker, R. and Jacobs, D.R. (2009) Association between Serum Gamma-Glutamyl Transferase and Cardiovascular Mortality Varies by Age: The Minnesota Heart Survey. European Journal of Cardiovascular Prevention and Rehabilitation, 16, 16-20. https://doi.org/10.1097/HJR.0b013e32830aba5c

[26] Ess, M., Mussner-Seeber, C., Mariacher, S., Lorsbach-Koehler, A., Pachinger, O., Frick, M., et al. (2011) Gamma Glutamyl Transferase rather than Total Bilirubin Predicts Outcome in Chronic Heart Failure. Journal of Cardiac Failure, 17, 577-584.

[27] Giannini, E.G. and Savarino, V. (2005) Liver Enzyme Alteration: A Guide for Clinicians. CMAJ, 172, 367-379. https://doi.org/10.1503/cmaj.1040752

[28] Paolicchi, A., Minotti, G., Tonarelli, P., Tongiani, R., De Cesare, D., Mezzetti, A., et al. (1999) Gamma-Glutamyl Transpeptidase-Dependent Iron Reduction and LDL Oxidation a Potential Mechanism in Atherosclerosis. Journal of Investigative Medicine, 47, 151-160.

[29] Paolicchi, A., Emdin, M., Ghliozeni, E., Ciancia, E., Passino, C., Popoff, G., et al. (2004) Images in Cardiovascular Medicine. Human Atherosclerotic Plaques Contain Gamma-Glutamyl Transpeptidase Enzyme Activity. Circulation, 109, 1440-1448. https://doi.org/10.1161/01.CIR.0000120558.41356.E6

[30] Paolicchi, A., Emdin, M., Passino, C., Lorenzini, E., Titta, F., Marchi, S, et al. (2006) Beta-Lipoprotein- and LDL-Associated Serum Gamma Glutamyl Transferase in Patients with Coronary Atherosclerosis. Atherosclerosis, 186, 80-85.

[31] Pompella, A., Emdin, M., Passino, C. and Paolicchi, A. (2004) The Significance of Serum Gamma-Glutamyl Transferase in Cardiovascular Diseases. Clinical Chemistry and Laboratory Medicine, 42, 1085-1091. https://doi.org/10.1515/CCLM.2004.224

[32] Ruttmann, E., Brant, L.J., Concin, H., Diem, G., Rapp, K. and Ulmer, H. (2005) Gamma Glutamyl Transferase as a Risk Factor for Cardiovascular Disease Mortality: An Epidemiological Investigation in a Cohort of 163,944 Austrian Adults. Cir culation, 112, 2130-2137. https://doi.org/10.1161/CIRCULATIONAHA.105.552547 
[33] Meisinger, C., Doring, A., Schneider, A. and Löwel, H. (2006) Serum Gamma-Glutamyl Transferase Is a Predictor of Incident Coronary Events in Apparently Healthy Men from the General Population. Atherosclerosis, 189, 297-302.

[34] Emdin, M., Passino, C., Michelassi, C., Titta, F., L'abbate, A., Donato, L., et al. (2001) Prognostic Value of Serum Gamma-Glutamyl Transferase Activity after Myocardial Infarction. European Heart Journal, 22, 1802-1807. https://doi.org/10.1053/euhj.2001.2807

[35] Fraser, A., Harris, R., Sattar, N., Ebrahim, S., Smith, G.D. and Lawlor, D.A. (2007) Gamma Glutamyl Transferase Is Associated with Incident Vascular Events Independently of Alcohol Intake: Analysis of the British Women's Heart and Health Study and Meta-Analysis. Arteriosclerosis, Thrombosis, and Vascular Biology, 27, 2729-2735. https://doi.org/10.1161/ATVBAHA.107.152298

[36] Strasak, A.M., Kelleher, C.C., Klenk, J., Brant, L.J., Ruttmann, E., Rapp, K., et al. (2008) Longitudinal Change in Serum Gamma-Glutamyl Transferase and Cardiovascular Disease Mortality. A Prospective Population Based Study in 76,113 Austrian Adults. Arteriosclerosis, Thrombosis, and Vascular Biology, 28, 1857-1865. https://doi.org/10.1161/ATVBAHA.108.170597

[37] Michele, E., Claudio, P., Alfonso, P. and Aldo, P. (2006) Gamma Glutamyl Transferase as a Cardiovascular Risk Factor. European Heart Journal, 27, 2145-2146. https://doi.org/10.1093/eurheartj/ehl151

[38] Biondi-Zoccai, G.G., Baldi, A., Biasucci, L.M. and Abbate, A. (2004) Female Gender, Myocardial Remodeling and Cardiac Failure: Are Women Protected from Increased Myocardiocyte Apoptosis. Italian Heart Journal, 5, 498-504.

[39] Lund, L.H. and Mancini, D. (2004) Heart Failure in Women. Medical Clinics of North America, 88, 1321-1345.

[40] Regitz-Zagrosek, V. (2003) Cardiovascular Disease in Postmenopausal Women. Climacteric, 6, 13-20.

[41] Maha, L.K. and Escott-Stump, S. (2000) Krauses Food, Nutrition and Diet Therapy. 10th Edition, W.B. Saunders Company, Philadelphia, 287-304.

[42] Sherwood, L. (2004) Human Physiology, from Cell to System. 5th Edition, Thomson Learning Inc., 81-83.

[43] Eitaute, J., Jurgia, G., Arunas, V., Marina, T., Janina, D. and Donatas, S. (2007) Sodium Valproate Stimulates Potassium and Chloride Urinary Excretion in Rats: Gender Differences. BMC Pharmacology, 7, 9-7. https://doi.org/10.1186/1471-2210-7-9

[44] Ahmed, J. and Weisberg, L.S. (2001) Hyperkalemia in Dialysis Patients. Seminars in Dialysis, 141, 348-356. https://doi.org/10.1046/j.1525-139X.2001.00087.x

[45] Bro, S. (2003) How Abnormal Calcium, Phosphate and Parathyroid Hormone Relate to Cardiovascular Disease. Nephrology Nursing Journal, 30, 275-283.

[46] Tucker, K.L., Chen, H., Hannan, M.T., Cupples, L.A., Wilson, P.W., Felson, D., et al. (2001) Bon Mineral Density and Dietary Patterns in Older Adults: The Farminghan Osteoporosis Study. The American Journal of Clinical Nutrition, 76, 245-252.

[47] Metra, M., Davison, B., Bettari, L., Sun, H., Edwards, C., Lazzarini, V., et, al. (2012) Is Worsening Renal Function an Ominous Prognostic Sign in Patients with Acute Heart Failure, The Role of Congestion and Its Interaction with Renal Function. Circulation: Heart Failure, 5, 54-62. https://doi.org/10.1161/CIRCHEARTFAILURE.111.963413 
[48] Bishop, M.L., Duben-Engelkirk, J.L. and Fody, E.P. (2000) Clinical Chemistry: Principle Procedure, Correlation. 4th Editon, Lippincott Williams and Wilkins, Philadelphia, 704.

[49] Jae-Young, S., Yeo-Jeong, C., Jeong-Min, K., Yoo-Ree, K.J., Jin-Sik, P., et al. (2011) Purification and Characterization of Helicobacter Pylori $\gamma$-Glutamyl Transpeptidase. Journal of Bacteriology and Virology, 41, 255-265. https://doi.org/10.4167/jbv.2011.41.4.255

[50] Hideyuki, S., Hidehiko, K. and Tatsurokuro, T. (1986) $\gamma$-Glutamyl Transpeptidase from Escherichia coli K-12: Purification and Properties. Journal of Bacteriology, 168, 1325-1331. https://doi.org/10.1128/jb.168.3.1325-1331.1986

[51] Azize, S. and Turay, Y. (2005) Activity Determination, Kinetic Analyses and Isoenzyme Identification of Gamma Glutamyl Transferase in Human Neutrophils. Journal of Biochemistry and Molecular Biology, 38, 343-349.

[52] Leslie, M., Shaw, L.W. and London, E.M. (1980) Electrophoretic, Kinetic, and Immuno Inhibition Properties of $\gamma$-Glutamyl Transferase from Various Tissues Compared. Clinical Chemistry, 26, 1523-1527.

[53] Lono, J.W., Shaw, L.M., Fetterolf, D. and Garfinkel, D. (1976) Determination of the Mechanism and Kinetic Constants for Hog Kidney Gamma Glutamyl Transferase. Biochemical Journal, 157, 609-617. https://doi.org/10.1042/bj1570609

[54] Shaw, L.M., Pither-Joyce, M.D. and McCallum, J.A. (2005) Purification and Cloning of a Gamma Glutamyl Transpeptidase from Onion (Allium cepa). Phytochemistry, 66, 515-522.

[55] Mason, J.E., Starke, R.D. and Van Kirk, J.E. (2010) Gamma-Glutamyl Transferase: A Novel Cardiovascular Risk Biomarker. Preventive Cardiology, 13, 36-41. https://doi.org/10.1111/j.1751-7141.2009.00054.x

[56] Ying, L., Yan, Y., Xiao-yu, L., Yang, H., Ibrahim, S.A. and Huang, W. (2013) Purification and Characterization of Two Enzymes Related to Endogenous Formaldehyde in Lentinula edodes. Food Chemistry, 138, 2174-2179.

[57] Tate, S.S. and Ross, M.E. (1977) Human Kidney $\gamma$-Glutamyl Transpeptidase. The Journal of Biological Chemistry, 252, 6042-6045.

[58] Shaw, L.M., London, J.W. and Petersen, L.E. (1978) Isolation of Gamma Glutamyl Transferase from Human Liver and Comparison with the Enzyme from Human Kidney. Clinical Chemistry, 24, 905-915.

[59] Blackshear, P.J. (1984) Systems for Poly Acrylamide Gelelectrophoresis. Academic Press, New York, Vol. 104, 237-256.

[60] Aberomand, M., Rahim, F. and Hosseini, S.A. (2008) Study of Alkaline Phosphatase from Human Hydatidiform. Pakistan Journal of Medical Sciences, 24, 471-474.

[61] Shaw, L.M., London, J.W., Fetterolf, D. and Garfinkel, D. (1977) Gamma Glutamyl Transferase: Kinetic Properties and Assay Condition When Gamma Glutamyl-4-Nitroanilide and Lts 3-Carboxy Derivative Are Used as Donor Substrates. Clinical Chemistry, 23, 79-85.

[62] Cairyfa, V.R., Gill, D. and Parola, A.H. (1998) Probing the Active Site of Adenosine Deaminase Phresponsive Fluorescent Competitive Inhibiter. Biophysical Chemistry, 70, 41-56.

[63] George, J. and Losos, J. (2010) The Living World. 6th Edition, McGraw-Hill, New York, 250.

[64] Chrisblosser, A. (2012) Effects of Temperature, pH, Enzyme Concentration, and Substrate Concentration on Enzymatic Activity. StudyMode.com, 10, 557. 
[65] Angeli, V., Tacito, A., Paolicchi, A., Barsacchi, R., Franzini, M., Baldassini, R., et al. (2009) A Kinetic Study of Gamma Glutamyl Transferase (GGT)-MediatedS-Nitrosoglutathione Catabolism. Archives of Biochemistry and Biophysics, 481, 191-196.

[66] Tietz, N.W. (1995) Clinical Guide to Laboratory Test. 3rd Edition, Saunders, Philadelphia, 124-127.

[67] Bryan, L.W. and Keith, W. (1981) General Principles of Biochemical Investigation. Principles and Techniques of Practical Biochemistry, 2nd Edition, 32-34.

[68] Dilda, P.J., Ramsay, E.E., Corti, A., Pompella, A. and Hogg, P.J. (2008) Metabolism of the Tumor Angiogenesis Inhibitor 4 N S Glutathionyl Acetyl Amino Phenyl Arsonous Acid. The Journal of Biological Chemistry, 283, 35428-35434. https://doi.org/10.1074/jbc.M804470200

[69] Stefan, M. and Hartwig, K. (2013) Drug-Drug Interactions in the Treatment of HCV among People Who Inject Drugs. Clinical Infectious Diseases, 57, 125-128.

\section{Submit or recommend next manuscript to SCIRP and we will provide best service for you:}

Accepting pre-submission inquiries through Email, Facebook, LinkedIn, Twitter, etc. A wide selection of journals (inclusive of 9 subjects, more than 200 journals)

Providing 24-hour high-quality service

User-friendly online submission system

Fair and swift peer-review system

Efficient typesetting and proofreading procedure

Display of the result of downloads and visits, as well as the number of cited articles

Maximum dissemination of your research work

Submit your manuscript at: http://papersubmission.scirp.org/

Or contact abb@scirp.org 